


\title{
Communication and accountability in the public sector: a possible overlap explored in the American and Italian contexts
}

\author{
Autor(es): $\quad$ Pavan, Aldo; Lemme, Francesca \\ Publicado por: Imprensa da Universidade de Coimbra \\ URL \\ persistente: URI:http://hdl.handle.net/10316.2/32177 \\ DOI: $\quad$ DOI:http://dx.doi.org/10.14195/978-989-26-0422-0_18 \\ Accessed : $\quad$ 26-Apr-2023 10:13:58
}

A navegação consulta e descarregamento dos títulos inseridos nas Bibliotecas Digitais UC Digitalis, UC Pombalina e UC Impactum, pressupõem a aceitação plena e sem reservas dos Termos e Condições de Uso destas Bibliotecas Digitais, disponíveis em https://digitalis.uc.pt/pt-pt/termos.

Conforme exposto nos referidos Termos e Condições de Uso, o descarregamento de títulos de acesso restrito requer uma licença válida de autorização devendo o utilizador aceder ao(s) documento(s) a partir de um endereço de IP da instituição detentora da supramencionada licença.

Ao utilizador é apenas permitido o descarregamento para uso pessoal, pelo que o emprego do(s) título(s) descarregado(s) para outro fim, designadamente comercial, carece de autorização do respetivo autor ou editor da obra.

Na medida em que todas as obras da UC Digitalis se encontram protegidas pelo Código do Direito de Autor e Direitos Conexos e demais legislação aplicável, toda a cópia, parcial ou total, deste documento, nos casos em que é legalmente admitida, deverá conter ou fazer-se acompanhar por este aviso.

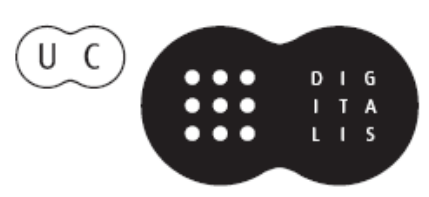




\section{Implementing Reforms in Public Sector Accounting}

Susana Jarge

Editor

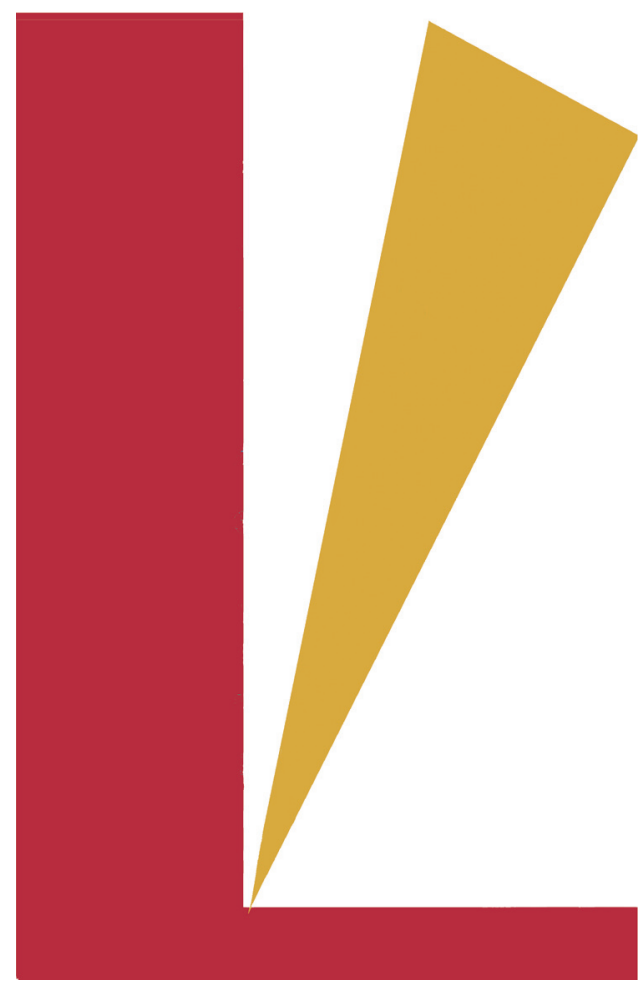


(Página deixada propositadamente em branco) 


\section{Implementing comparative Interational Reforms Governmental in Public Sector Accounting Accounting}

Susana Jorge Editor 
COORDENAÇÃO EDITORIAL

Imprensa da Universidade de Coimbra

Email: imprensauc@ci.uc.pt

URL: http://www.uc.pt/imprensa_uc

CONCEPÇÃO GRÁFICA

António Barros

\section{PAGINAÇÃO}

Simões \& Linhares, Lda.

\section{EXECUÇÃO GRÁFICA}

Simôes \& Linhares, Lda.

ISBN

978-989-8074-39-3

DEPÓSITO LEGAL

$281657 / 08$

\section{OBRA PUBLICADA COM O APOIO DE:}
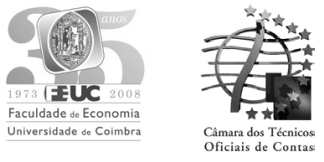

(C) Agosto 2008, IMPRENSA DA UNIVERSIDADE DE COIMBRA 
Aldo Pavan

Francesca Lemme

\section{COMMUNICATION AND ACCOUNTABILITY IN THE PUBLIC SECTOR: A POSSIBLE OVERLAP EXPLORED IN THE AMERICAN AND ITALIAN CONTEXTS}

\section{Introduction}

Democracy is the basis of all modern western societies. Freedom, fairness and equity are its fundamental values that were cherished and fought for over the centuries. Its embryonic yet fascinating origins may be encountered in ancient Greece, the cradle of political communication. In fact, the Athenian agora was the first physical space where the open exchange of ideas, feelings and information among citizens was likely to directly influence face-to-face decisional processes in the name of public interest. Such 'communication space' showed a sharp relational orientation since it encompassed all the participants in the process. Its aim was the maintenance of a common sense of the citizenship. In fact, on one thing the classical Greeks were adamant: they liked living among equals, they enjoyed equality before the law and equal opportunities to speak in public assemblies (Minogue, 1995). Greek citizenry inaugurated this form of popular sovereignty that we call 'de visu democracy'. Knowledge was power and since then the two concepts of democracy and information have ineluctably been linked.

The relationship between democracy and information is somewhat crucial still today, since it inevitably governs the relationship established between elected officials and citizens. It is not by chance that western democracies are now sharing a widespread tendency to focus their efforts on effective communication processes with the citizenry. Undoubtedly, they are stimulated by the ongoing proliferation of Information and Communication Technologies (ICT) whose implementation is becoming a strategic accountability medium. Moreover, ICT are even supposed to lead us all towards an era of utopian and somewhat unrealistic 'electronic democracy' where we should be able to vote by phone or through text messages, participate in discussion forums and opinion polling by clicking on a website or become much more involved in public choices comfortably staying at home. Nevertheless, the role of ICT in promoting 'electronic democracies' is a very controversial issue even from a philosophical perspective ${ }^{1}$.

\footnotetext{
${ }^{1}$ See the Italian website of philosophy, www.swif.uniba.it/.
} 
Its overestimation is conceivably based on the wrong assumption that democracy is a synonym for 'connection' or 'connectivity' and that the concept of 'direct democracy' might have the same meaning as the expression 'computerized democracy'. Castells (2002) pointed out that technologies cannot be defined by means of such dichotomies as good vs. bad or positive vs. negative: according to him, all that we know about ICT is that they are not neutral for their users.

Taking a jump back in time, political communication has dramatically changed its features and structures with the advent of mass media. In fact, as the underlying social communities became too large to allow direct representation, their political institutions started mirroring such growing process by implementing more and more complex forms of political organization. As a consequence, the process of political representation gradually took the place of direct personal involvement and 'communication spaces' became less and less relational while incorporating almost only informative and vertical flows of information from elected bodies to the citizenry. The advent of mass media played a crucial role in strengthening the foregoing restyling of political communication processes. By contrast, more recently, the diffusion of ICT and the astonishing growth of the Internet have played a key role in reshaping communication spaces while giving them back their original relational features.

To come to the crux of the matter, it is reasonable to assume that the whole population of a certain country is a potential user of the accounts of public sector organizations since this would accord with the basic notions of democracy (Jones and Pendlebury, 2000). Thus, the necessity to cope with the citizens' information needs would imply a natural shift from the concept of 'political communication' to 'political accounting', intended as an integrated informative system transforming economic, financial, and possibly, social and environmental outcomes of public action into understandable information for the citizenry. In a word, citizens call for governmental accountability. In such an instance, the composition of the word clearly helps us to understand what governments are expected to be according to the citizens' standpoint: in fact, AccountAbility is the ability to be accountable and goes hand in hand with the ability to answer the information needs of users while supporting their decisional processes (Pavan and Lemme, 2006).

With all this in mind, we will investigate whether and to what extent governments that are communicatively oriented to their citizens may be assumed as politically accountable to them. Thus, we will strive for a theoretical correspondence among the communication theory, the theory of agency and the concept of accountability. Pragmatically speaking, this would mean that the more governmental financial and non financial information targeted towards citizens is able to mirror the prerequisites of the communication theory, the more it would be likely to result in a successful encounter with the citizens themselves.

To test the foregoing hypothesis, we will rely on the Internet, given its characteristics of easy accessibility, full-time availability, immediate selectivity and social relevance. Then, we will refer to the American and Italian governmental environments, the former being the most prominent and well-structured federal state in the history and the latter being presently involved in a devolution process which is declared to evolve into a federal system. The study will be carried out at a federal level for the USA and at a central level for Italy on the basis of a multidisciplinary approach 
involving such disciplines as accounting, public sector management and linguistics. To do so, for each country we will select a reference book available on the net. The selection will be carried out by searching those publications combining governmental communication processes with the citizenry with the technical contents of official financial documents. Thus, with reference to the American context, we will analyse the GASB ${ }^{2}$ Concepts Statement N. 3 Communication Methods in General Purpose External Financial Reports that contain Basic Financial Statements (available at www.gasb.org). With reference to the Italian one, we will refer to a governmental publication issued by the Italian Department for Public Administration ${ }^{3}$. The title is How to be accountable to citizens ${ }^{4}$, available at www.funzionepubblica.gov.it/. Then, we will gather all the legally adopted financial documents we have found on the internet that were referred to in the foregoing reference documents ${ }^{5}$. All the material was downloaded in September 2006. It was issued during the years 2005 and 2006 and is still available on the websites of the Government Accountability Office (GAO) - www.gao.gov/ - and the National General Accounting Department ${ }^{6}$ - www.rgs.mef. gov.it - regarding the USA and Italy respectively. To investigate how the conceivable relationship between communication and accountability compared in the two contexts, the analysis will be conducted from a double standpoint. From a theoretical perspective, we will analyse the possible overlap between the communication theory, the theory of agency and the concept of accountability. Conversely, from a pragmatic standpoint, we will focus on the contents of the financial information conveyed by means of official documents that will be investigated from a qualitative and quantitative perspective.

The paper will be structured as follows. Next section will provide key data on the most significant theoretical framework this study is based on. We will analyse the basic assumptions of the theory of agency and the constituent elements of the communication theory and we will try to show a possible theoretical overlap. Section 2 will describe the methodological assumptions that were the basis of our writing. Sections 3 and 4 will be completely devoted to the analysis of how the concepts of communication and accountability work differently in the American and Italian realities. Section 5 will describe the limitations of the present study. In the final section we will draw up some conclusions.

${ }^{2}$ The GASB is the Governmental Accounting Standard Board, a standard-setter for American State and Local Governments.

${ }^{3}$ As we will see at grater length while investigating the Italian context, the Department for Public Administration is an institutional entity that was created as a part of the Prime Minister's Office to promote effectiveness and innovation in Italian public administrations.

${ }^{4}$ The English expression 'How to be accountable to citizens' is a translation for the Italian title 'Rendere conto ai cittadini.'

${ }^{5}$ On closer inspection, the Italian reference book does not directly indicate the kinds of financial documents to be disclosed, but it clarifies that the communicative process should involve budgetary and reporting practices. Thus, we gathered all the official documents we have found on the cited website.

${ }^{6}$ An English translation for 'Ragioneria Generale dello Stato.' 


\section{Theoretical framework}

The theoretical framework the present paper is based on, is the theory of agency. This theoretical construction developed in the 1970s and originally stemmed from the managerial theory of the firm. Nowadays it refers to a variety of contexts where a specific social interaction is established (Ross, 1973). This interaction can be explained as follows. There are two social parties: one is designated as 'the agent' that acts for, on behalf of, or as representative for the other designated as 'the principal in a certain domain of decision problems (Zamagni,1982; Arrow, 1987; Mayston, 1993).

In economics, the problem of motivating one party to act on behalf of another is known as 'the principal-agent problem'. Such an approach may have full application in the public sector since modern democracies are living witnesses of: a) contractual delegations between principals (the citizenry or electorate) and agents (policy-makers or elected assemblies); b) some kind of advantage to the citizenry - while delegating political bodies - that otherwise would not be in the position to directly and commonly manage public resources; c) a feeble capability of the citizenry to fully assess both the general outcome of the agent's performance and the compliance with favourable actions; d) the lack of immediate control of the citizenry over elected assemblies or policy-makers (Althaus, 1997). In such a context the concept of 'accountability' seems to act as a fundamental working criterion governing the relationship between electors and elected officials while stimulating the implementation of appropriate disclosure practices and knowledge-sharing processes. Accountability, in fact, involves different elements as social interdependence between the principal and the agent, and consequent processes of communication - from the agent to the principal - and assessment - from the principal to the agent (Pavan and Reginato, 2005; Sinclair, 1995).

\subsection{Communication theory, theory of agency and political accountability}

Communication is the transmission of codified information from a source to a recipient through a channel. The communicative phenomenon, described in Table 1, needs the following constituent elements: the source of information, the message, the recipient, the feedback process, the channel, the code, and finally, the context (Shannon and Weaver, 1949; Cherry, 1957; De Vito, 1970; Robinson, 1977).

The table shows the constituent elements of a standard communication process happening in a certain context. The source generates a message by elaborating and transmitting ideas, feelings, emotions, or more generally, information. The source is expected to be aware of the understanding capabilities of the recipient in order to intentionally create a message in the most meaningful way (Perrone, 2006). The message is the object of the communicative process. It is made up by what is communicated and how the information is communicated and should be structured in a very friendly way for the recipient, otherwise what is sent could be very different from what is grasped and the initial message could finally result in a dysfunctional interpretation. The transmission of the message is continuously undermined by the spread of 'noise', an expression used by scientists to refer to whatever disturbing element affecting a communication process. The recipient receives the message 
Table 1 - The Communication Process

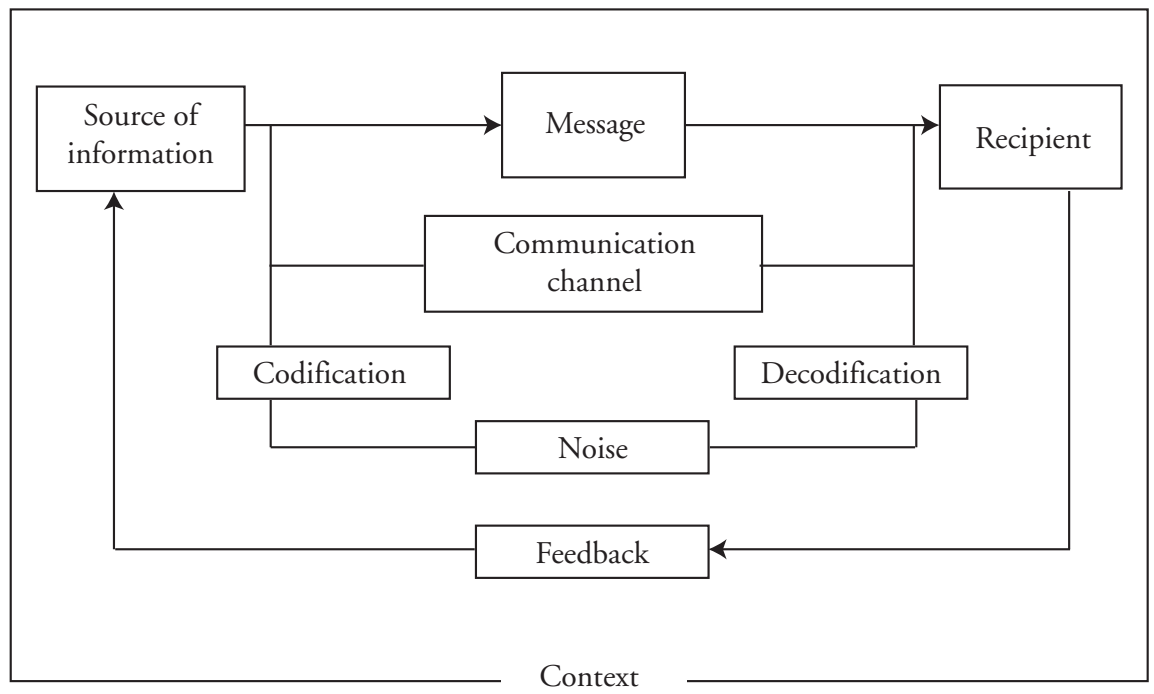

and acts as a key-participant in the communication process by stimulating feedback information. The feedback is a powerful tool that the source has at its disposal to assess the effectiveness of the underlying communication process and consists in the reply of the recipient to the communicative stimulus transmitted by the source. The channel is the medium throughout which the message is sent. Voice, gestures and written documents can be possible channels in a communication process. The code is a shared and well-structured system of signs. Language intended as a system of communication in speech and writing is the best known code. What is to be underlined here, is that a single language may generate many other sub-codes that necessitate codification and decodification As far as we are concerned, technical and professional jargons fit the case. The context is the physical, psychological, sociological and cultural scenario where the communication process happens and inevitably has some kinds of repercussions on the communication process itself.

Table 2, combines the essential elements underlying the communication theory, the theory of agency and the concept of accountability as formerly described. Their correspondence is highlighted in bold, italic and underlined type.

A little more in depth, the principal (i.e. the citizenry) being the ethical owner of public resources has the right to be informed of their use. Conversely, the agent (political bodies) is responsible to the citizenry for the use of public resources and should be prepared to accept the principal's penalties for their improper use (boxes 1, 2, 3, 4 and 9). To enhance codification and decodification processes, the agent should choose the most appropriate channel of communication (boxes 5,6 and 7): this would reduce the spread of 'disturbing factors' (box 8). The foregoing communication process takes place in a certain context (box 10). 


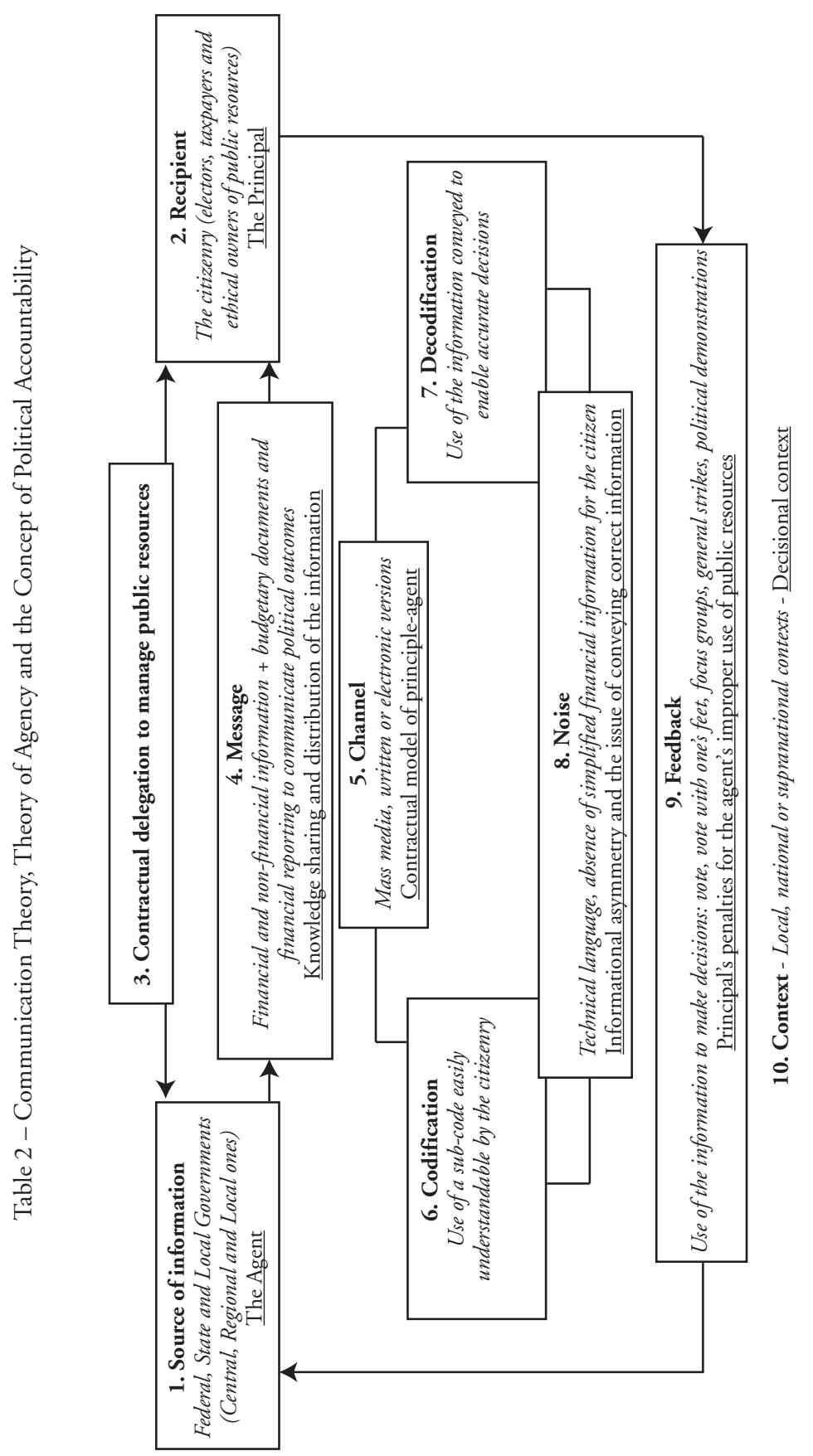


To conclude, given the foregoing theoretical overlap, it is reasonable to assume that the more the information conveyed to citizens by governments is likely to show a substantial degree of compliance with the assumptions of the communication theory, the more the concept of accountability will be likely to permeate governmental disclosure practices. In such a perspective, political accountability seems to go hand in hand with transparent, intelligible, concise and effective implementation of communication methods, intended as the ultimate resource the agents possess to clearly communicate political outcomes and actions to their principal. As a result, financial information is expected to act as a cornerstone for governmental communication since, if properly used, it summarizes the state of health of public finances, the costs and benefits of public actions as well as their present and future repercussions.

\section{Methodological assumptions}

From a methodological perspective, the present paper may be essentially framed in the ambit of exploratory comparative research (Smith, 2003). In fact, the study consists in a dual case analysis carried out on the Italian and American accounting environments. In both contexts, emphasis will be given to the degree of compliance between the communication theory, the official financial documents prepared by governmental bodies and the reference documents. To enjoy research synergies, the analysis will be carried out from a multidisciplinary standpoint encompassing economics, public sector accounting (Lüder et al., 2003; Montesinos and Vela, 2002) - and linguistics (Biber et al., 1998; McEnery and Wilson, 2001; Meyer, 2002; Oakes, 1998).

As anticipated in the introductory section, from an accounting perspective the investigation will begin by critically analysing the two reference books we found on the net that directly combined communication processes - between governments and their citizens - with accounting, budgeting and reporting processes as well as technical information. They will be analysed on the basis of the content-analysis methodology in order to infer communication structures and attitudes. Thus, on the basis of the same methodology, we will analyse the online official documents that were referred to in the reference books. On the one hand, we will emphasize what is communicated, how the information conveyed is communicated and what kinds of citizens' information needs are plausibly satisfied. On the other, we will investigate the degree of compliance between communication features envisaged in the reference books and official financial reports and budgetary statements. Then, we will construct a parallelism between the basic assumptions of the communication theory and the communicative skills performed by the two countries. To this end, linguistically speaking, all Italian and American documents will be gathered in two different corpora, analysed on the basis of the linguistic methodology known as 'corpus linguistics'. Such a methodology consists in the study of linguistic phenomena through statistical procedures that highlight how words behave in texts while pointing out their occurrences, most frequent collocates and even hidden textual information that otherwise could remain undiscovered in syntactical constraints. The corpus-based analysis will be carried out through the software WordSmith Tools, an integrated suite of programs looking at how words are intentionally combined to create texts. The software basically provides the user with 
three analytical tools that, when skilfully combined, result in an advanced language investigation: the Wordlist, the Concordancer, and the Keyword ${ }^{7}$. The above mentioned linguistic approach will be used to corroborate such findings achieved through the analysis of the contents and will enable us to draw up some interesting conclusions.

\section{Governmental communication and accountability in the USA}

The document we chose as a reference point to carry out our analysis of the US governmental online communication is the Concepts Statement N. 3. The choice came as no surprise since the statement, issued by the GASB in April 2005, is available on the GASB website and directly portrays some key communication prerequisites that should inform the process of financial reporting at the outset.

\subsection{The GASB Concepts Statement N. 3}

The Statement is intended to provide a conceptual framework of interrelated objectives and fundamental concepts that can be used as a basis for establishing consistent financial reporting standards and identifying objectives and fundamental principles of financial reporting.

Its core aspect is that there is a strong relationship between communication and financial reporting as well as a clear correspondence between the contents of the book on the one hand and the communication theory and its basic assumption on the other. Communication is intended as a relational process where each participant in the process is expected to play an active role.

It is structured in 60 paragraphs showing a concise and easy-readable format. The page of contents shows several main component parts: introduction, scope and purpose; General Purpose External Financial Reports (GPEFR) and Basic Financial Statements (BFS); communication and financial reporting, communication methods in GPEFR that contain BFS. The concepts shaped in Statement N. 3 - as the title immediately suggests - only apply to GPEFR that contain BFS, notes to financial statements and Supplemental Information (SI) presented with BFS.

The Statement addresses the following recipients: the GASB, the preparers of GPEFR that contain BFS and the ultimate users. They all have one thing in common: they use information to make decisions. Its main topics are: 1) communication and financial reporting; 2) communication and presentation methods; 3) communication and the objectives of financial reporting.

${ }^{7}$ The Wordlist shows all the component words of a selected text file by alphabetical or frequency order and provides an overall statistical window. The basic assumption in frequency studies is that word occurrences are meaningful indicators of the prominence the authors of texts transmit to readers. The Concordancer is a program making concordance files. It looks for selected words and displays their pragmatic use by highlighting the linguistic context where they actually appear. Thus, it finds out 'collocations', that are regular word combinations. That is why linguistics often refers to concord programs as tools aimed at displaying the so-called 'KWIC' (i.e. Key Word In Context). The Keyword shows words that are semantically peculiar to the text under analysis. 
As for the relationship between communication and financial reporting, the statement directly refers to the different categories of an indented audience. Emphasis is given to the concepts of 'communication process' and 'effective reporting'. In the communication process, financial reports play an instrumental role in communicating results, being a pure means of communication rather than the content of the communication itself. The Statement also clarifies the responsibilities of all the participants in the foregoing process of communication. The GASB continuously studies the needs of users of financial reports by identifying the types of information required for supporting decisions and assessing accountability. It helps preparers not only by providing guidance on the content of financial reports, but also by selecting the communication methods that should be used to convey messages. The preparers of GPEFR must do their best to clearly transmit a message to users. Their responsibility covers the selection of events that are essential to assist the users in assessing accountability and making decisions, the quantification of such events and the choice of the methods of presentation. Conversely, the user must obtain a reasonable understanding of public finance activities and of the fundamentals of governmental financial reporting and has to study the messages conveyed with reasonable diligence and analytical skills.

As for the relationship between communication and presentation methods, the Statement gives due relevance to the three different concepts of 'communication methods', 'communication channels' and 'presentation methods'. A communication method is a financial reporting construct that conveys information to users of GPEFR and helps meet one or more of the objectives of financial reporting. It deals with the placement of a particular item of information within GPEFR that contain BFS. According to Statement N. 3, an item of information is a candidate for inclusion in GPEFR if it is consistent with the objectives of financial reporting and meets the basic characteristics for the communication of information in financial reports clearly stated in the GASB Concepts Statement N. 1 (understandability, reliability, relevance, timeliness, consistency, comparability). A method of presentation is a way chosen by preparers for transmitting financial information to user: it can be narrative, tabular or graphic. The channel of communication is the means by which financial information is made available to users (printed version, various forms of electronic media).

Moreover communication and presentation methods should enhance the process of financial reporting as described in the GASB Concept Statement N. 1 that is fundamentally oriented to: a) assist governments in fulfilling their duty to be publicly accountable and enable users to assess that accountability; b) assist users in evaluating the operating results of the governmental entity for the year and c) assist users in assessing the level of services that can be provided by governmental entities and their ability to meet their obligations as they become due. 
The Consolidated Financial Report (CFR) for the fiscal year $2005^{8}$ is available through the Treasury's website at www.treas.gov/. Similarly to a corporation's annual report, it can be defined as the federal government's general purpose report of accountability to the American public on its finances and presents consolidated and summarized financial information of the federal government agencies and departments. It was audited by the Government Accountability Office (GAO) in December 2005, and then, submitted to the Congress by the Department of the Treasury in coordination with the Office of Management and Budget (OMB) by $31^{\text {st }}$ March 2006. Thus, the document under scrutiny possesses all the characteristics Statement N. 3 prescribes and can be reasonably assumed as the 'GPEFR containing BFS' with respect to the federal government.

The CFR is structured in six main sections: 1) the Management's Discussion and Analysis (MD\&A); 2) the financial statements; 3) the notes to the financial statements; 4) stewardship information; 5) supplemental information and 6) the GAO's report. Sections 2 and 3 contain audited information. The Secretary of the Treasury makes some opening remarks.

The MD\&A gives evidence of the management's perspective on reported financial data, provides the President, the Congress and the American people with information about the financial results and position of the federal government and shows the interrelation among the five financial statements. Such statements are: the statement of net cost, the statement of operations and changes in net position, the reconciliation of net operating cost and unified budget deficit, the statement of changes in cash balance from unified budget and the balance sheet. The consolidated financial statements point out relevant results such as: the net cost, the net operating cost, the budget deficit, the increase in operating cash balance, and finally, the net position. The notes to the financial statements contain important disclosures and details about the items placed in the balance sheet. Among them: significant accounting polices; components of cash and other monetary assets; detailed information about property, plant and equipment; depreciation methods; federal debt securities held by the public and accrued interest; federal employee and veteran benefits payable; environmental and disposal liabilities; information about contingencies. The section devoted to stewardship information contains detailed information about the so-called stewardship assets that are non-operational resources such as natural, historical, cultural and collection-type heritage assets the government manages for the benefit of the nation. Consequently they are not likely to be used to face current and future obligations and they are not encompassed in the balance-sheet. The section of supplemental information mainly focuses on the distribution of the federal tax burden among individuals and corporations.

At this point, it is necessary to give some extra information contained in the GAO's section of the CFR. In fact, the contents of GAO's report are crucial to understand the degree of compliance between the basic requirements of GASB Statement N. 3

\footnotetext{
${ }^{8}$ The American fiscal year conventionally starts on October 1 and ends on September 30.

${ }^{9}$ As we will see, the GAO'S report is an essential part of the CFR.
} 
and the communication processes with the American people implemented by the Federal Government.

According to the GAO, the CFR is intended to a) provide an overall view of the annual financial results of operations and the financial position of the federal government, including long-term commitments and obligations; b) demonstrate accountability both for raising money through taxation and for spending monetary resources according to the laws and regulations governing the federal government's budgets and financial operations; c) report on the federal government's operating performance, accounting systems and internal control and d) demonstrate the federal government's stewardship over its resources.

It is here useful to remember that the CFR is submitted by the Secretary of the Treasury and the Director of the OMB to the President and the Congress and that, in order to evaluate the reliability of the information conveyed, the GAO is required to annually audit some of its specific components. The MD\&A, the stewardship information, and the supplemental information are not required to be audited, and as a consequence, the GAO does not express an opinion on them. Conversely, the five official financial statements and the notes to the financial statements are subject to the GAO's close scrutiny. In this relation, the GAO may express: a) an unqualified opinion (underlining fair presentation of information and compliance with GAAP and significant laws and regulations); b) a qualified opinion (underlining some exceptions to an unqualified opinion); c) an adverse opinion (underlining unfair presentation) or d) a disclaimer of opinion in case of serious lack of information. In the GAO's report issued in December 2005, the Comptroller General pointed out that the GAO was not able to express an assessment of the CFR for the ninth consecutive year and listed the main impediments preventing the GAO itself to render an opinion.

Such impediments are a) the existence of serious financial management problems at the Department of Defence, b) the federal inability to account and reconcile intergovernmental activities; c) the government's ineffective process used to consolidate financial statements, and d) the government's inability to establish and maintain effective internal control. Moreover, according to the Comptroller General there are two significant matters of emphasis. The first is the nation's fiscal imbalance. In this relation, he highlighted that 4 out of 24 governmental agencies ${ }^{10}$ - that accounted for $58 \%$ of government's reported total assets and $25 \%$ of the federal net cost - received disclaimers of opinion. He argued that on the basis of the reported information, the long-term fiscal outlook combined with the envisaged budget deficit are destined to deteriorate gloomily without significant changes on the spending and revenue side of the budget and that the present reporting model is not able to transparently render the actual range of the government's responsibilities and obligations. The second refers to the potential impact of restatements. In fact, at least 7 out of 24 Federal Agencies restated certain of their fiscal year 2004 financial statements to correct errors.

${ }^{10} \mathrm{We}$ are referring to the National Aeronautics and Space Administration (NASA), the Department of Defence, the Department of Homeland Security (DHS) and the Department of Energy. 
To conclude, according to the GAO's report, all the foregoing elements are likely to encumber the intelligibility of the reported information, and as a result, readers are strongly cautioned that the amounts reported in the CFR may not be entirely reliable and may lead to a misleading and unrealistic picture of the overall governmental performance and financial condition.

\subsection{A computerized language analysis: overall statistics, Wordlists and Concordances}

The American corpus consists of the CFR. The following windows retrieved by WordSmith show what the analytical tools ${ }^{11}$ extrapolated from the text under scrutiny. In this section, the windows generated through the program will be shown in the same way as the software retrieved them and the results of Wordlists and Concordances will be often referred to in a combined form.

The following table shows the quantitative statistical results exploited through WordSmith.

Table 3 - Statistical data

\begin{tabular}{|l|r|}
\hline Number of pages & 185 \\
\hline Number of sentences & 1,695 \\
\hline Number of tokens & 39,456 \\
\hline Number of types & 3,047 \\
\hline Type/token ratio (on a percentage basis) & 7.72 \\
\hline Average sentence length (in words) & 23.22 \\
\hline Average word length & 5.06 \\
\hline
\end{tabular}

As Table 3 clearly shows, the CFR is made up of 185 pages, 1,695 sentences, 39,456 words (tokens) and 3,047 different words (types or repeated words). Thus the type/ /token ratio is an indicator of lexical variety. Sentences are averagely made up of 23 words and words are averagely made up of 5 letters. Through Wordlist tool, each word or expression is retrieved from the corpus by indicating both its absolute and relative frequency. Table 4 shows the thirty-five most frequent words in the corpus.

\footnotetext{
11 We refer to Wordlist and Concordancer described in Section 2.
} 
Table 4 - The most frequent words in the American corpus

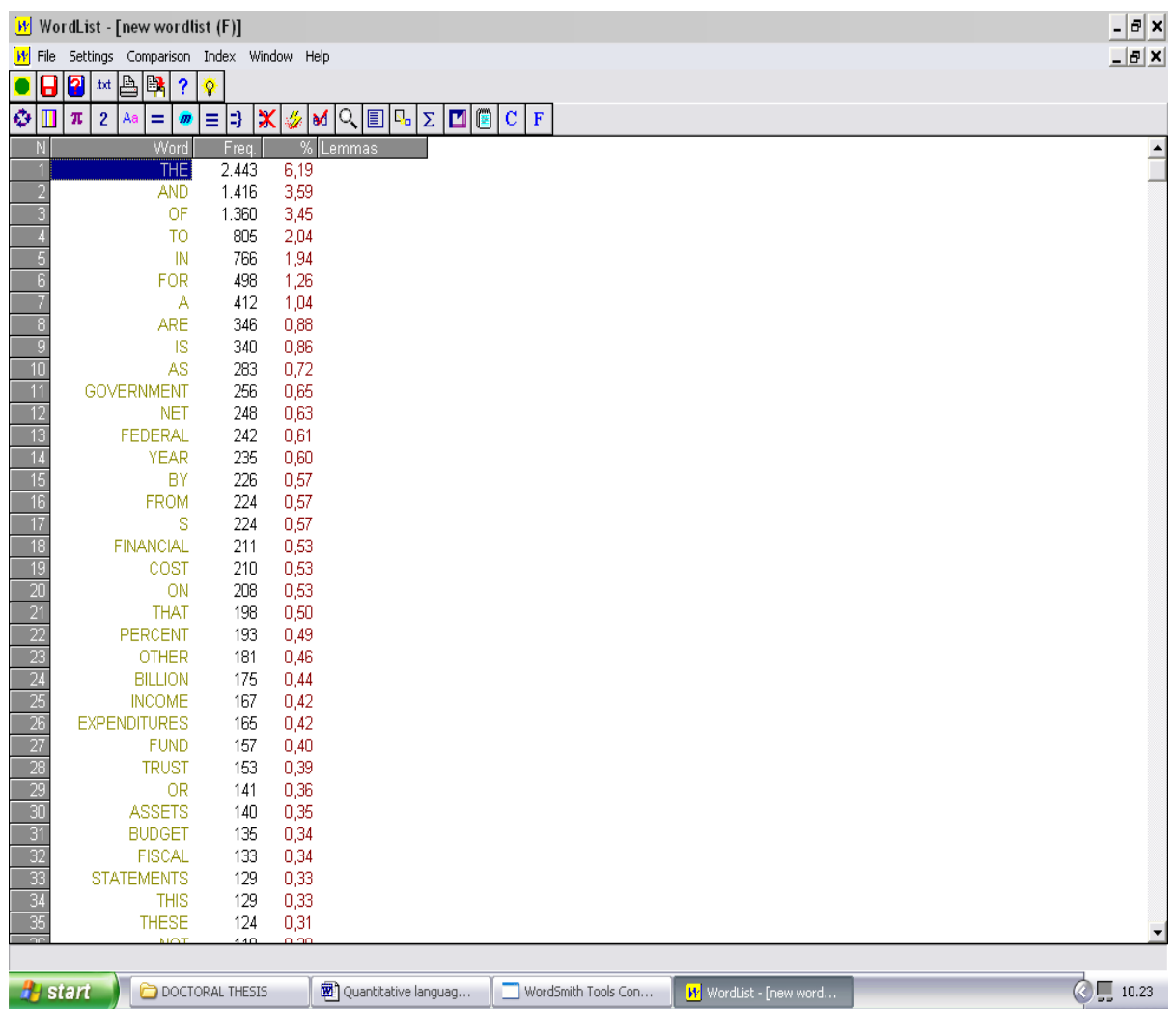

From a semantic standpoint, the most frequent words pertain to the economic and public sector field. The words that seem deserving attention are: 'government', 'federal', 'financial', 'expenditure' and 'budget'. We also looked for the concordances of the above mentioned words and we found that the words 'government' and 'federal' often 'unnecessarily' collocate since the CFR is referred to the American Government which is undoubtedly a federal one: it seemed to us that the strong federal tradition of the USA left an important trace in the redundant expression 'the federal government'. The word 'financial frequently collocates with 'statements' to indicate the homonymous section of the CFR. What is to be underlined is that the collocations of 'expenditures' disclosed a very interesting collocational behaviour. As Table 5 clearly shows, the foregoing word is frequently preceded by the adjective 'future'. In fact, given the several occurrences of the expression 'present value of future expenditures' preparers of the CFR are likely to evoke, maybe in an embryonic way, their intent to pursue some sort of intergenerational equity. 
Table 5 - KWIC for the word 'expenditures'

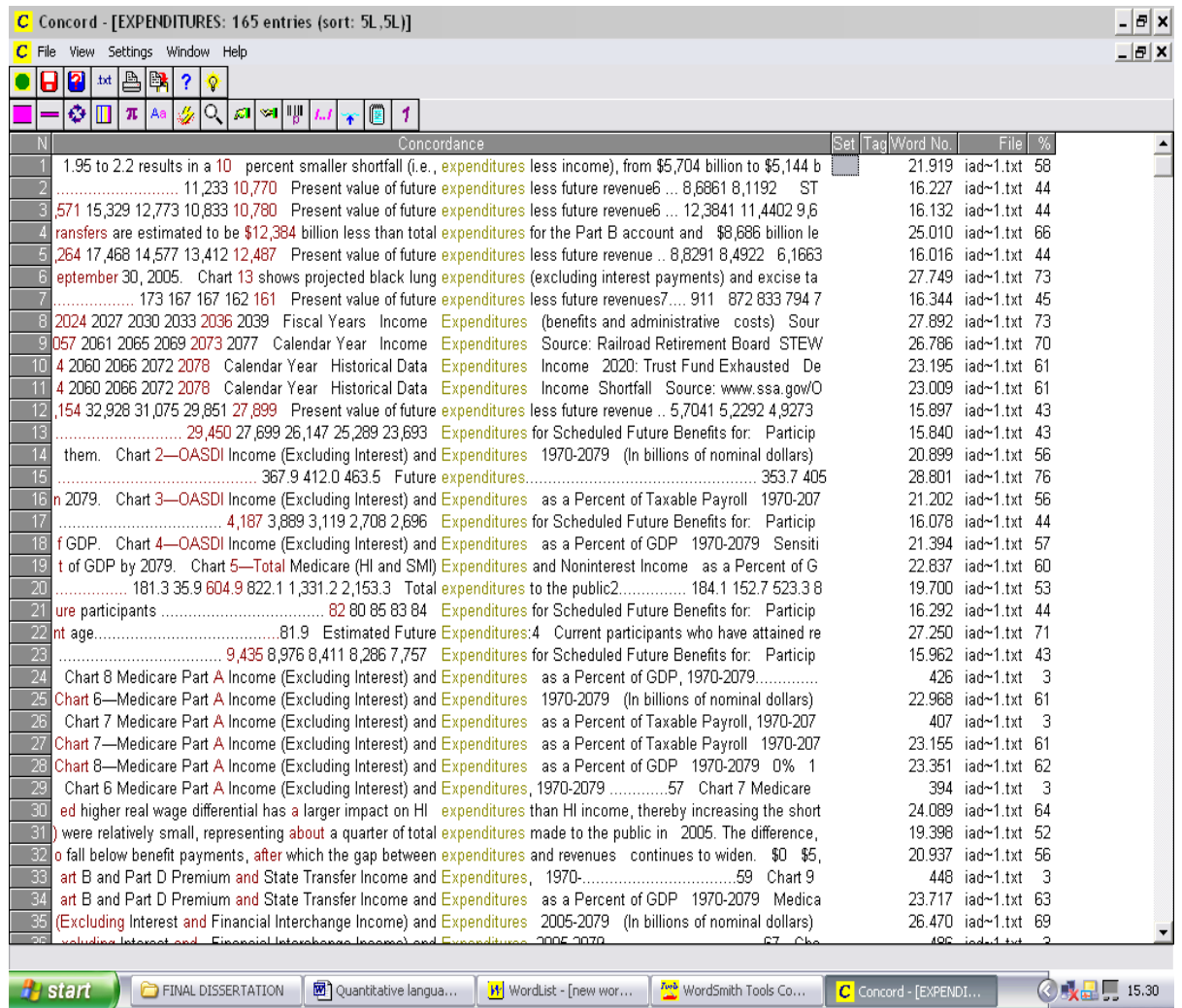

We also used Wordlists to analyse the collocational behaviour of two-word and three-word expressions. Among them, 'trust fund, 'the federal', 'the government', 'financial statements', 'social security', 'the financial', 'the public', 'net cost', 'present value', 'stewardship information', 'net operating cost', 'the present value', 'debt held by', 'the projection period' and 'from the public' seem semantically relevant. We have already devoted a few words on the expressions 'the federal, 'the government' and 'financial statements'; but the relevance given to the expression 'stewardship information' comes new to us. With 56 occurrences it seems to act as the most quoted component in the CFR. In our opinion, this does not happen by chance. In fact, stewardship information covers all the governmental non-operational resources and responsibilities that are not included in the balance sheet. Consequently, the disclosure of such kind of information constitutes a matter of great interest for the preparers of the CFR.

We turn now our attention to a set of expressions that - to some extent - should evoke communication processes. With this in mind, we first looked for the expressions 'information', 'democracy', 'communication', 'accountability', 'citizens', 'American people', 'to the public', 'from the public', and then, we analysed their frequencies and the specific contexts they appeared in the CFR. We surprisingly noted that such words as 
'democracy' and 'accountability' were not cited at all in the CFR. In addition, 'citizens' and 'communication' respectively appeared twice and once. The expression 'American people' scored 12 but only twice it was related to communication. Moreover, the word 'information' showed 108 occurrences, but 96 out of 108 it collocated with 'stewardship'. In addition, expressions such as 'to the public' and 'from the public' occurred only 12 and 20 times respectively to indicate borrowing operations.

\subsection{Communication theory and accountability in the USA: the most significant empirical results}

The investigation has been carried out both from a qualitative and quantitative perspective. Qualitatively speaking, the governmental communication in the USA shows a very high level of integration with the communication theory. In fact, GASB Statement N. 3 directly refers to the communication process by describing its basic assumptions in the same way as the communication theory does. Moreover it lists the participants in the cited process and emphasizes their roles and responsibilities. Thus, the focus on communication permeates the whole structure of the American accounting reporting model.

Moreover, the interrelated interpretation of the contents of the CFR and the objectives of financial reporting allows us to firmly state that, at first sight, the American accounting context is characterized by both an overall attainment of such objectives and a sharp consistency between the conceptual framework portrayed in Statement N. 3 and the government's accounting practices.

Furthermore, the clear definition of the scope, purpose and contents of GPEFR, communication methods, methods of presentations, communication channels and objectives of financial reporting seem intended to wrap readers in a communicative environment where there is nothing else for them but to become aware of the communicative intents of the preparers.

Nonetheless, in the absence of the GAO's opinion on the CFR's reliability for the ninth consecutive year, we became surprisingly aware of a communicative paradox since an apparently perfect communication model adversely affected accountability.

In this respect, the computerized language analysis was of invaluable help in supporting us to understand the foregoing communicative paradox. In fact, on the one hand, through wordlists and word frequencies we learnt that the most frequent words in the CFR pertain to the economic and public sector fields, that the strong federal tradition of the country is given semantic relevance, that there is a redundant reference to the dichotomy between the diachronic effects of the present governmental policies and their conceivable reverberations in the future. Overall statistics enabled us to underline the conciseness of sentences and paragraphs that, from the preparers' standpoint, is intended to strengthen understandability. On the other hand, the absence of certain words that semantically refer to such concepts as 'democracy', 'accountability' and 'communication process' together with the findings retrieved through the KWIC format depict a language use that seems to be in line with what the GAO called an "unrealistic and misleading picture of the federal government's overall performance, financial condition and future fiscal outlook." 
To conclude, the present investigation reveals a sharp counterbalance in the American governmental communication: the adherence of the accounting information to the contents of the communication theory is likely to enhance the understandability and intelligibility of the reported information and potentially boost the capacity of the government to be accountable to the citizens. But it is not able to solve once and for all the accountability issue.

\section{Governmental communication and accountability in Italy}

The title of the reference book we chose is How to be accountable to citizens and was issued in 2005 by the Department for Public Administration. As the term suggests, this department is an institutional entity purposely created in 1983 as a part of the Prime Minister's office, to promote effectiveness and innovation in Italian Public Administrations. Since 2005, the publication has been available at www. funzionepubblica.gov.it/. It represents the joint effort of a research team including both theoreticians and practitioners. It is mainly targeted on regional and local government but the authors firmly declared that it was also intended for the central government. The book is divided into five main chapters preceded by a foreword written by the Minister for Public Administration, plus a general introduction. In the absence of legal constraints and a compulsory legislative framework governing the so-called stakeholder report ${ }^{12}$, the implementation of the related contents and principles in the Italian governmental informative system is still carried out on a voluntary basis.

\subsection{The reference book "How to be accountable to citizens"}

We have already mentioned that the Italian reference book How to be accountable to citizens does not directly indicate the kinds of financial documents that are expected to be included while communicating with the citizenry. Instead, it refers to the stakeholder report as an accountability medium that should enhance understandability and transparency.

The book is intended to provide public administrations with a multi-functional reporting model that goes beyond the traditional financial reporting process. It is tailored to local, regional and central governments and tries to answer two main crucial questions. The first relates to the motivations that should stimulate public administrations to be accountable to citizens and the second deals with the procedural introduction of the new reporting process. It also shows a sharp communicative nature governing the relations that public entities have with the outside. Politically speaking, it should strengthen the democratic bases and the social legitimacy of the public action by means

\footnotetext{
12 With such an expression we refer to that kind of reporting process aimed at defining, analysing and highlighting the social outcomes of the public actions that cannot be expressed through traditional financial reporting. The cited outcomes are shown from the point of view of different categories of stakeholders. Social and Environmental Report is another possible expression.
} 
of transparent political choices and shared assessment of them by the general public. Moreover it should act as a feedback mechanism to improve internal governance and orient planning, programming and control-based activities. Finally, it is expected to stimulate civil servants' professional skills, motivation and vocation.

The basic assumption of the book is that Italian citizens are increasingly demanding accountability. The stakeholder report is a unique and innovative accountability medium, interpreting the government's necessity to effectively communicate public decisions, activities, actions and outcomes. The implementation of the stakeholder report may represent: a) a way of highlighting the essence of social and public action; b) a precious relation-oriented expedient aimed at stimulating an immediate rapport between policy-makers and citizens and c) a valuable opportunity for public administrations to adopt both new methodologies and more effective tools while defining, programming and evaluating the overall implementation of public policies.

The book is made up of five chapters aimed at investigating: a) whom the government must be accountable to and why; b) the different forms of stakeholder reporting; c) the basic principles of stakeholder reporting; d) the construction of the stakeholder report and e) the effectiveness of the stakeholder report.

In detail, as for the forms of the stakeholder report, preparers may stress the importance of different aspects characterizing the social effects of public action. To completely fit communicative objectives, they should be purposely combined. The book identifies the following kinds of stakeholder reporting: a) stakeholder annual report; b) political report; c) environmental reporting; d) gender report. As for the relationship with the budget planning and the operational management control, the implementation of such strategical form of reporting is not depicted as an erratic and autonomous communicative activity that disregards all the other traditional forms of financial reporting. Conversely, all the components of the reporting activity are expected to interact. The stakeholder report is introduced to implement an additional and circular process enabling public administrations to be accountable to citizens by first relying on the fundamental set of values summarized in political and electoral programs. Such values and programs should be 'translated' through budgeting and reporting documents that, in turn, should provide for useful information to be adequately re-packaged on the basis of stakeholders' information needs. Finally, as for the construction of the stakeholder report and the definition of the conditions underlying an effective use of such form of reporting, the authors identify the following main subsequent phases: preliminary setting of stakeholder reports, construction and issuance. From an organizational perspective, what is crucial is that all the foregoing phases should involve the whole public entity.

What is worthy of note, is that the Italian government does not prepare any stakeholder report at a central level. Thus, in striving for a truthful representation of Italian governmental online communication with the citizenry, we decided to look for online documents that referred to the Italian budgetary and reporting processes. 


\subsection{The analysis of the Italian online documents}

On the net we found the following five documents: the Economic and Financial Planning Document for the time-span 2006-2009 (Documento di Programmazione Economica e Finanziaria - DPEF), the annual budget for the year 2006, the Financial Act for the year 2006, the Forecasting Document for the year 2007 (Relazione Previsionale e Programmatica - RPP) and the Management Discussion Statement (Relazione Generale sulla Situazione Economica del Paese - RGE) for the year 2005.

The economic and financial planning document is a descriptive file containing both general public targets and strategies purposely-created to reach them. It covers a time-span of four years (from 2006 to 2009) and has a strong political value since it must pass the close scrutiny of the Parliament. It ranks as cornerstone to which future governmental policies must comply with. It shows the operating cash inflows and outflows; the portion of the budget deficit to be financed through public debt increases and the European recommendations on public finance and its restoration. The budget is annually prepared by the National General Accounting Department and therefore submitted to the close scrutiny on the part of the Parliament. Finally, it is transmitted to central administrations, departments and ministries for execution. It envisages the expected costs recorded by nature and functional destination as well as their corresponding cash outflows. The financial act is the most formal and technical document in the financial manoeuvre. Data encompassed in its paragraphs and sub-paragraphs are consistent with the objectives of the economic and financial planning document and represent the benchmark against which the official budget as well as all the budgeted costs must be measured. The forecasting document is an accompanying file the Government presents to the Parliament by the end of September. It traces a careful economic domestic outline and explains programme targets and pragmatic strategies together with background information useful to understand clearly the whole governmental financial manoeuvre. It shows the most significant economic weaknesses and the ongoing economic trends covering public finance, public spending, taxation, labor market, temporary work, and irregular immigration. The management discussion statement is made up of three volumes: the first one refers to the most significant trends in the international and domestic economies; the second one is made up of three different sections that deal with: a) the contribution of the different economic sectors to the creation of GDP and its distribution; b) the labor market and social security; c) public finance and synthetic macroeconomic data. Finally, the third volume is made up of macroeconomic statistical data and tables.

What is worthwhile noting here is that the first four documents belong to the budgetary process whilst only the last one refers to the process of financial reporting. It goes without saying that the 'budget' still remains the universe of the Italian governmental online communication.

\subsection{A computerized language analysis: Overall statistics, Wordlists and Concordances}

The Italian corpus consists of the five documents listed in the former section. The following windows retrieved by WordSmith show what the analytical tools 
extrapolated from the text under scrutiny. As for the American context, the windows generated through the program will be shown here in the same way as the software retrieved them and the results of Wordlists and Concordances will be often referred to in a combined form.

The following table shows the overall statistical results exploited through WordSmith.

Table 6 - Statistical data

\begin{tabular}{|l|r|}
\hline Number of pages & 1,500 \\
\hline Number of sentences & 10,843 \\
\hline Number of tokens & 612,337 \\
\hline Number of types & 13,851 \\
\hline Type/token ratio (on a percentage basis) & 2.26 \\
\hline Average sentence length (in words) & 56.47 \\
\hline Average word length (in letters) & 4.16 \\
\hline
\end{tabular}

As Table 6 clearly shows, Italian documents are made up of 1,500 pages, 10,843 sentences, 612,337 words (tokens) and 13,851 different words. Sentences are averagely made up of 56 words.

Through Wordlist tool each word or expression is retrieved from the corpus by indicating both its absolute and relative frequency. Table 7 shows the thirty-five most frequent words in the corpus. The words that seem to deserve attention are: 'totale',

Table 7 - The most frequent words in the Italian corpus

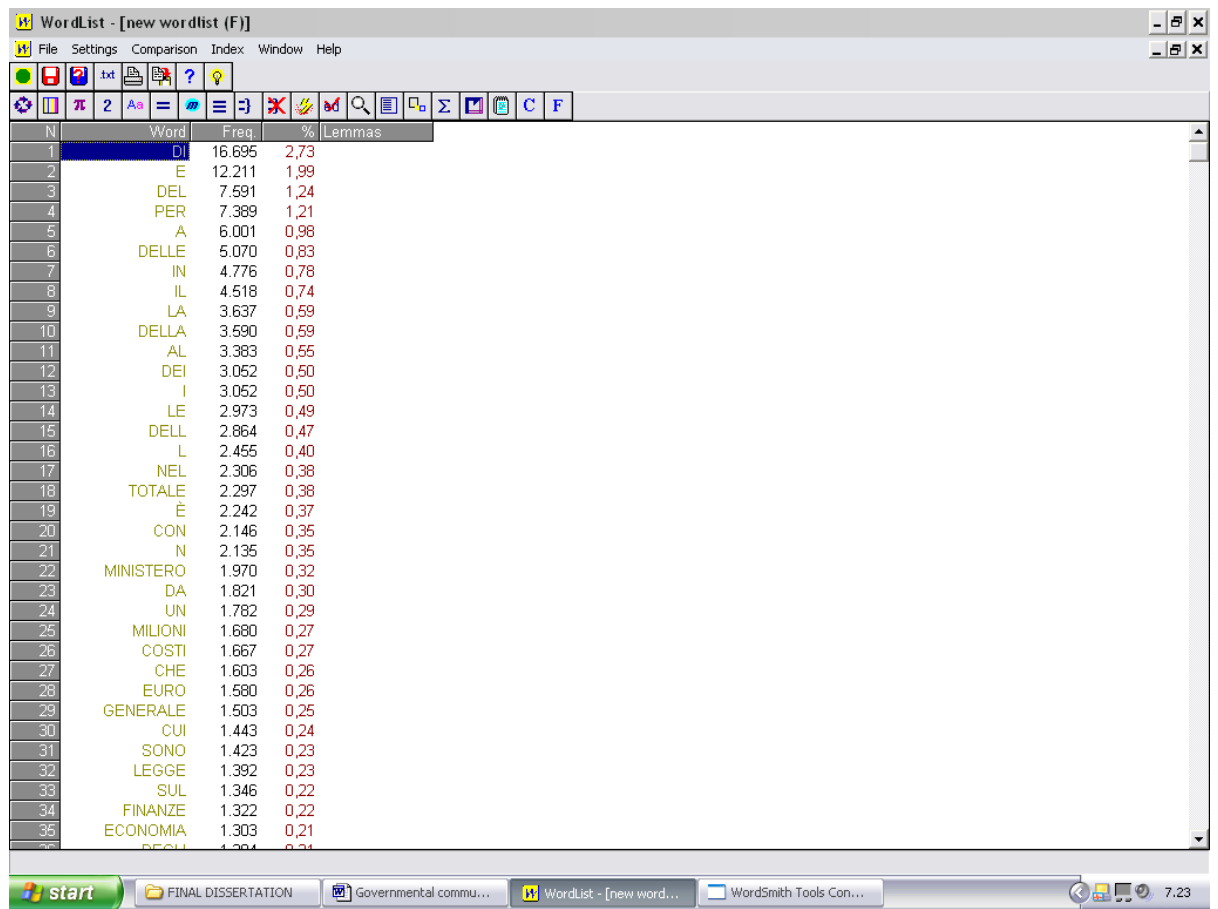


'ministero', 'costi', 'generale', 'legge', 'economica', 'servizi', 'stato', 'relazione', 'comma', 'lavoro', 'spesa', 'decreto'. The word 'totale' (total), usually collocates with 'costo' (cost). The words 'ministero', 'costi' and 'spesa' (ministry, costs and expenditure, respectively) mainly occur in the budget section and seem to emphasize the role of central public administrations. But, what is worthwhile noting here is that such words never collocate with their most reasonable economic ally: the word 'revenue'. This might suggest that costs and revenues are not intended consistently with the concept of accrual accounting. On the contrary, they are likely to be treated as 'independent' monetary values, much more in line with the concept of cash accounting. The words 'generale' and 'economica' scored well since they are component words of either the name of governmental organizational units or the title of the official financial documents themselves. The words 'legge', 'decreto' and 'comma' (act, delegated law and paragraph of a law) witness the legal tenor of the Italian budgetary process. The words 'stato', 'servizi' and 'relazione' (State, services/public utilities and relation) should evoke the central political realm as well as the natural democratic counterpart of the regional and local governments: the citizenry. Nevertheless, from the collocational behavior of the words 'stato', 'comunicazione', 'pubblico' and 'cittadini', (State, communication, public and citizens) we realized what follows. The word 'Stato' is mainly used in the expressions 'budget dello stato' (the budget of the Central Government) and 'ferrovie dello stato' (State-owned railway company) and is not intended to emphasize the central state or the distinction between the central state itself and local governments. 'Comunicazione' is used to refer to specific programs of the Ministry of Education and University as well as to legal duties to be accomplished. The commonest expressions are: sciences of communication, communication theory, foreign languages and communication, multimedia communication and journalism, notifications and running prescription of communications. But there is no reference to actual communication processes with the public. Moreover the word 'pubblico' is used to indicate the public sector, public securities, public debt, public transportation and law but never refers to the general public. As far as we are concerned, the collocational behavior of the word 'cittadini', shown in Table 8 , is somewhat unique. In fact, citizens are mainly mentioned to indicate fiscal duties to be compulsorily accomplished and the foreign people (immigrants) that necessitate legalization.

\subsection{Communication theory and accountability in Italy: the most significant empirical results}

The investigation has been carried out both from a qualitative and quantitative perspective. Qualitatively speaking, governmental communication in Italy does not seem to have reached the standards of the communication theory. What is to be underlined is that the central government does not prepare the stakeholder report. The theoretical overlap between the communication theory, the theory of agency and the concept of accountability seems feeble and does not pass through the traditional reporting system. Instead, it involves an additional document (the stakeholder report) whose contents are intended to enrich the usual concept of accountability. Moreover, it must be remembered that its introduction is voluntary still today. 


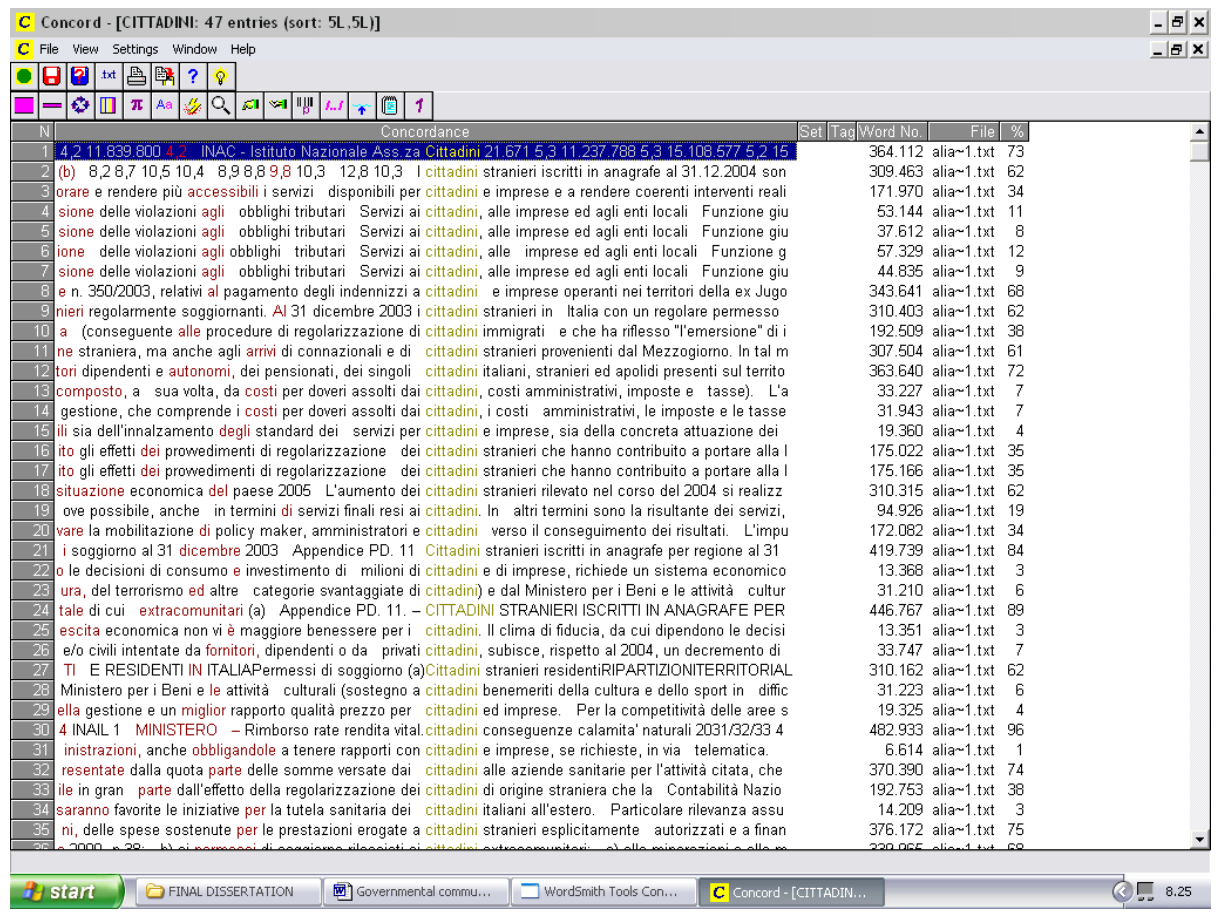

Another datum that deserves mention is that the preponderance of budgetary data compared to reporting ones is a proof of the legal tenor of the budget process that focuses on the budgetary comparison as a tool enabling elected assemblies to pose legal and political constraints on the spending power of executive branches (Mussari et al., 2003). While speaking about the relationship between the theory of communication and the theory of agency, we firmly underlined the instrumental role of financial documents in assisting the citizens' decisional process. It is probably necessary to specify that such a role primarily refers to reporting data since the budgetary ones are often subject to revision. As a result, it is reasonable to assume that Italian citizens are not able to carry out unbiased decisional processes on the basis of budgetary data only. Thus, it would be successful in terms of transparency and fairness if reporting documents were given the same prominence as the budgetary ones. Nevertheless, this does not seem to be the case in Italy. Moreover, in the absence of a clear indication of the objectives of financial reporting, it is not possible to fully assess the accomplishment of the citizens' information needs.

From the computerized language analysis we learnt that the full size of the Italian documents (more than 1,200 pages for budgetary documents only) is not in line with the basic assumption of the communication theory. In addition, the juridical lexis is the predominant one while there is no strong semantic reference to communication processes with the citizenry. All the foregoing elements enable us to conclude that the Italian governmental online communication is barely understandable by the average citizen 
and is characterized by pure formalism and sharp auto-referential features. Despite the existence of some comforting signs of innovation, communication processes with the citizenry still seem distant from the goals set out by the communication theory. As a result, Italian communication does not seem to have faced all the challenges offered by a well-targeted use of the Internet and a proper implementation of communicative attitudes.

\section{Limitations}

The fundamental limitation of this study is the reliance on two reference books mainly targeted on state, regional and local governments to analyse communicational behaviours at federal/central levels. In Italy, the stakeholder report is explicitly intended for all governmental levels despite the fact that it is mainly implemented by local governments. As for the USA, public sector is characterized by the existence of two different accounting standard-setting boards (Allen, 2002; Chan, 2002): the Governmental Accounting Standard Board (GASB), created in 1984, that sets the so-called Generally Accepted Accounting Principles (GAAPs) intended for state and local governments and the Federal Accounting Standard Advisory Board (FASAB), created in 1990, that issues federal accounting standards. Although the two standard-setters are thoroughly independent, there are ongoing contacts at the board level to share attitudes, ideas and thoughts on related accounting topics. One crucial implication is that there is a present greater and greater conceptual convergence in federal and state/local accounting and reporting standards. Since we did not find any publication addressing federal communication methods in a way that is parallel to GASB's Concepts Statement No 3, we decided to contact the FASAB to have some useful indications. The request was timely because it relates to a conceptual framework project the FASAB has recently started. The project - Key Components of the Financial Report - focuses on the methods of communicating information in federal financial reports and one of the project objectives is to develop guidance for determining when a means of communicating information should be used. The project is one of several phases of the FASAB's initiative to revisit its conceptual framework and is currently in the early research stage. Moreover, part of the project will involve reviewing existing concepts on the GASB's literature. Consequently, it was reasonable to refer to the GASB's work to analyse the CFR of the US federal government from a communicative perspective.

\section{Conclusions}

The present paper has tried to analyse the American and the Italian governmental environments in order to investigate whether and to what extent governments that are communicatively oriented to their citizens may be assumed as politically accountable to them. By implication, we investigated the theoretical relationship between the two concepts of communication and accountability. Thus, by analysing the basic assumptions of both the theories, we found that they show a close theoretical correspondence. On this ground, it was reasonable to assume that the more the governmental financial information is able to mirror the prerequisites of the communication theory, the more it 
would be likely to result in a successful encounter with the citizenry. At the same time, we became soon aware of the fact that such a theoretical overlap is likely to work in a different way according to the pragmatic contexts being investigated. With this in mind, the analysis strived to find empirical confirmation on the basis of a multidisciplinary approach encompassing content-analysis and corpus-based research.

Emerging from the study are the common themes of governmental accountability, political communication and political accounting. In fact, throughout online political communication, ICT and the Internet in particular became new communication spaces focusing on the relationship between governments and citizens while stimulating the maintenance of the common sense of the citizenry.

On the American front, the concept of accountability ranks - at first sight - as the cornerstone of all financial reporting and requires the US government to answer the citizenry as a justification for the raising of public resources and the purposes for which they are used. To really understand the overlap being investigated, stress must be put on the concept of reliability. Accountability, in fact, requires fair representation and full disclosure of financial data. To summarize, in the USA it is generally accepted that the government is established by the people and for the people. Citizens, electors, taxpayers and others interested in governmental operations believe that they are entitled to have open access to governmental information. Probably, this is the reason for which we found that the relationship between the communication theory and accountability is 'internal' to financial reporting even if it does not involve the budgetary process. In fact, communication processes address reporting documents only. Their structures, contents and interrelations are clearly stated and seem to be intended to enhance public understandability. The overall financial information conveyed to the citizenry is consistent with the primary objectives of financial reporting. The computerized language analysis highlighted that the overall Consolidated Financial Report (CFR) is made up of 185 pages, 39,456 words and 1,695 sentences. The language used pertains to the economic and public sector fields. The conciseness of sentences, the use of financial jargon, the clear definition of objectives, the representation of reporting documents and the presence of stewardship information seem to prove the completeness of the governmental information and the orientation to citizens. Nevertheless, the fact that the reference book does not mention any budgetary documents - since the combination of accounting and communicative issues is targeted towards reporting documents only - makes the concept of accountability weaker. Moreover, despite the fact that the reference book and the CFR show a sharp integration with the theory of communication, in the absence of the GAO's opinion for the ninth consecutive year, the American government has been found to convey misleading and unrealistic information by the GAO itself. According to GAO, the completeness of financial data and their synthetic disclosure are not enough to achieve an acceptable degree of reliability that still remains the actual thorn in the American government's 'flesh'.

On the Italian front, the concept of accountability encompasses both budgetary and reporting processes. In addition, it entails a shift from traditional accounting - emphasizing formal documents and mere figures - to the stakeholder report. Such innovative form of reporting is intended as a tool of democratic participation showing the citizenry the overall social and environmental effects of the public action. It goes without saying that it is also expected to form an integrated informative system, 
if properly combined with traditional reporting. The first datum to be underlined is that the contents of the reference book How to be accountable to citizens have not been implemented yet at a central level. Moreover, the declared targets referred to public administrations being involved in the implementation of the stakeholder report rather than to the citizenry. In the absence of a clear reference to the objectives of financial reporting, it is difficult here to assess accountability. From the documents we found on the net, we realized that emphasis was given to the budget, whilst the reporting side of the accounting process was almost completely disregarded. In this relation, it might be useful to underline that budgeting chronologically precedes reporting. Moreover, it provides reporting with the benchmarks to measure financial performances. But, financial reporting has other functions besides monitoring budgetary execution. Among them, a significant one is the provision of data to external user as the fair presentation of the governments' financial position and over-time modifications. A bit more in depth, all this might suggest that the absence of reporting documents is a proof of the mandatory role of the budget that continues to set almost only spending caps. The computerized language analysis highlighted that the online documents lacked synthesis. In fact, they are made up of more than 1,500 pages, 10,843 sentences and 612,337 words. The usual language belongs to the juridical field and does not encourage either understandability, or simple reading. The investigated overlap between communication and accountability is 'external' to traditional accounting processes, but is supposed to encompass both budgeting and reporting. Moreover the incompleteness of the information conveyed represents its crucial weakness.

To summarize, in the American context, accountability is 'internal' to traditional financial reporting; it disregards budgetary documents whilst financial reporting is able to mirror the prerequisites of the communication theory. The information conveyed to the citizenry is complete, concise and clear but, according to the GAO, it is seriously weakened by lack of reliability. Conversely, in Italy accountability is 'external' to traditional financial reporting; it is mainly targeted towards budgetary documents and the lack of synthesis together with the incompleteness of the information conveyed to the citizenry are the most significant weaknesses. The reasons for such diversities are controversial and call for further elucidation in future research.

Nevertheless, apart from the above-mentioned diversities that are peculiar to the American and the Italian contexts, what is worthwhile noting here is that the strict adherence to the prerequisites of the communication theory does not seem to act as a cornerstone of accountability in the investigated contexts. In fact, we realized that although the construction of the analysed overlap between the communication theory and the concept of accountability is the most significant theoretical attainment in this study, it nonetheless represents a pragmatic failure in the two countries.

\section{References}

Allen, T. L. (2002), Public accountability and governmental financial reporting, in Models of public budgeting and accounting reform, OECD Journal on budgeting, Vol. 2, Suppl. 1.

Althaus, C. (1997), The application of agency theory to public sector management, in G. Davis, B. Sullivan \& A. Yeatman (eds.), The New Contractualism?, Centre for Australian Public Sector Management. 
Arrow, K. J. (1987), Equilibrio economico e l'impresa nella teoria dell'equilibrio economico, in Equilibrio incertezza, scelta sociale. Il Mulino, Bologna.

Biber, D.; Conrad S. and Reppen R (1998), Corpus linguistics. Investigating language, structure and use. Cambridge University Press.

Castells, M. (2002), La nascita della società in rete. Università Bocconi Editore.

Chan, J. L. (2002), Government budget and accounting reforms in the United States, in Models of public budgeting and accounting reform, OECD Journal on budgeting, vol. 2, supplement 1.

Cherry, C. (1957), On human communication, Cambridge.

Department of the Treasury (2005), The consolidated financial report of the United States for the year 2005.

De Vito, J. A. (1970), The psychology of speech and language, New York.

Dipartimento della Funzione Pubblica (2005), Rendere conto ai cittadini.

GASB (1987), Concepts Statement N. 1, Objectives of financial reporting, Norwalk.

GASB (2005), Concepts Statement N. 3, Communication methods in general purpose external financial reports that contain basic financial statements, Norwalk.

Jones, R. and Pendlebury, M. (2000), Public sector accounting, Pearson Education Limited, Harlow.

Lüder, K. and Jones, R. (eds.) (2003), Reforming governmental accounting and budgeting in Europe, Frankfurt am Main, PricewaterhouseCoopers, Fachverlag Moderne Wirtschaft.

Mayston, D. (1993), Principals, agents and the economics of accountability in the new public sector, Accounting, Auditing \& Accountability Journal, Vol. 6.

McEnery, T. and Wilson, A. (2001), Corpus linguistics. Edinburgh University Press.

Meyer, C.F. (2002) English corpus linguistics. An introduction. Cambridge University Press.

Minogue, K. (1995), Politics, a very short introduction. Oxford University Press.

Montesinos, V. and Vela, J.M. (2002) Innovations in governmental accounting. Boston, Kluwer.

Mussari, R.; Grossi, G. and Castelnuovo, A., (2003), Italy, in Reforming governmental accounting and budgeting in Europe, Frankfurt am Main, PricewaterhouseCoopers, Fachverlag Moderne Wirtschaft.

Oakes, M. P. (1998), Statistics for corpus linguistics. Edinburgh University Press.

Pavan, A. and Lemme, F. (2006), Central government financial information and user-orientation on the Internet in Italy and the USA, in Accounting reform in the public sector: mimicry, fad or necessity, Evelyne Lande and Jean Claude Scheid (eds.), Paris.

Pavan, A. and Reginato, E. (2005), Prospettive di accountability ed efficienza nello stato italiano. Giuffrè Editore, Milano.

Perrone, F. (2006), Comunicazione interpersonale. Edizioni Utet, Torino.

Robinson, W. P. (1977), Linguaggio e comportamento sociale, Bologna.

Ross, S. A. (1973), The Economic Theory of Agency: The Principal's Problem, American Economic Review, Vol. 63, N. 2, Papers and Proceedings of the Eighty-fifth Annual Meeting of the American Economic Association (May, 1973).

Shannon, C. E. and Weaver, W. (1949), The mathematical theory of communication, Urbana.

Sinclair, A. (1995), The Chameleon of Accountability: forms and discourses, Accounting Organizations and Society, Vol. 20, n. 2/3, 219-237.

Smith, M. (2003), Research methods in accounting. Sage Publications, London.

Zamagni, S. (1982), a cura di, Conoscenza e economia, in Saggi di filosofia della scienza economica, La Nuova Italia Scientifica. 




C - 